TP Periodica Polytechnica Architecture

48(1), pp. 17-22, 2017

https://doi.org/10.3311/PPar.11183

Creative Commons Attribution (i)

RESEARCH ARTICLE

\section{European Influences: Local Solutions The Pulpit Altar as a Means of Expression}

\author{
Béla László Harmati ${ }^{1 *}$
}

Received 13 June 2017; accepted 19 June 2017

\begin{abstract}
In the Evangelical-Lutheran Church, the use of pulpit altars has never been obligatory or exclusive. However, the importance of the cult centre in the increasingly uniform internal space as a principle of interior design brought this form into life; one that is exclusively characteristic of the Evangelical-Lutheran Church. In Hungary, pulpit altars were built from the time of the Edict of Tolerance (1781) until the end of the 19th century. In their form, they were mostly to local specifications and options, which played an important role over and above the strong Western European influences. In the evolution of the typology, it is not only the interaction between the Catholic and Reformed elements that can be pinpointed but also the national differences so characteristic within the Evangelical-Lutheran Church.

The Slovak, German and Hungarian speaking Lutheran communities, with their diversified and unique relationships, had enriched the forms used in church furnishing in Hungary; this can best be seen in the pulpit altars constructed in the same period.
\end{abstract}

\section{Keywords}

pulpit altar, Evangelical-Lutheran Church, European Influences

\footnotetext{
${ }^{1}$ Hungarian Lutheran Museum

"Corresponding author, e-mail: blharmati@gmail.com
}

Today in Hungary, there are approximately 475 Evangelical-Lutheran churches, houses of prayer, or those of worship in the common use of the Reformed and the Evangelical-Lutheran churches. As far as we know, in contrast to the destruction and decay that has taken place, there are still some 183 smaller or larger pulpit altars in these buildings. However, in accordance with the documents of the archives, there were many more built after the Edict of Tolerance.

Although there have been separate pulpits and altars built since the Middle Ages, the appearance of the pulpit and the minister preaching from the pulpit altar simply broke and changed the related centuries-long econographic traditions and structures. The decorations, themes and symbols appearing on the pulpit altar did not bring anything new in themselves compared to the previous practice. However, that the Word, the Word preached and the Eucharist were connected meant real novelty. This required a brand new structure for the applied pictures, differing considerably from the previous practice. In German areas, where there was a greater possibility for continuous development compared to Hungary, pulpit altars can be readily divided into several thematic groups. As there have been many papers dealing with the architectural antecedents, the role of Joseph Furttenbach Sr. and Jr. and that of Leonhard Christoph Sturm, as well as the effect they had on Hungary, this aspect will not be discussed in this paper.

In Hungary, it is possible to define four larger groups of pulpit altars that are easy to distinguish. These groups are primarily typological and not iconographical categories.

The Hungarian pulpit altars only partially followed their German antecedents as far as their forms and developments are concerned; the German influences were only indirectly asserted. The reasons behind this are the different financial and social backgrounds on the one hand, and the great timely shift on the other. In the Carpathian Basin, for almost 200 years before the Edict of Tolerance, there had been no real opportunity for Evangelical-Lutherans to have a say in church construction and develop the interior to their choice. 
However, from the end of the $18^{\text {th }}$ century onwards, there were processes in Hungary different from those applied in the German provinces. The patrons' influence on the construction and the internal decoration of the churches were significantly less in Hungary than in other European countries with a high proportion of Protestant inhabitants. The effect and involvement of "major" maecenases can be identified mostly based on the painted or gilded coat-of-arms placed on the altars and the upper circle (Nemescsó and Uraiújfalu for example). Over and above this, the richer ornamentation of the "patrons' pew" could also be an indication; it needs to be noted, however, that neither the size nor the location of these pews (benches) were as special as those of their German counterparts, i.e. the patrons' upper circles. Social differences within a given church were usually shown by the strict rules of the seating order (Kósa, 1993:pp. 28-33; pp.74-77.). Churches were mostly constructed based on the financial support of communities led by people belonging to the lower or middle segment of the noble class.

From an art history perspective, the most interesting period is the one covering the end of the $18^{\text {th }}$ century and the beginning of the $19^{\text {th }}$ century. It is one of the interesting and in the beginning seemingly contradictory, features of the era that the opportunity for artistic evolution for the Lutherans in Hungary happened at a turning point in historical styles; in the ideological atmosphere of the declining baroque and the nascent enlightenment, with classicism busy executing innovations of form. By itself, the very fact that the majority of the Evangelical-Lutheran churches and their furnishing bore the stylistic marks of the previous era, namely those of the baroque of the Counter-Reformation is something that cannot be identified with the defence of conservativism. The reasons should be searched for elsewhere.

After having expelled the Turks from Hungary, the par excellence style of church and secular reconstructions penetrated deep into each layer of society. A high number of public institutions, offices, residential buildings and rural churches following typical architectural designs embodied this style. "While becoming folkish, great styles transform, adapt and become implanted into the domestic tradition" - wrote Lajos Fülep (Fülep, 1951). In the case of the Lutherans, the same process could be noticed in the Carpathian Basin.

The majority of the late baroque or the classicising late baroque Hungarian pulpit altars Hungary originate from the same period. Most of them were made between the end of the $18^{\text {th }}$ and the first or second decade of the $19^{\text {th }}$ century. Significant differences can be traced - both from formal and iconographical aspects - between not only the Hungarian and the German pulpit altars, but also among the Hungarian types.

The most important and apparent difference, compared to the German practice, is represented by the lack of the organ above the pulpit altar (the sole exception is the pulpit altar of the Lutheran church of Markt Alhau, Burgenland (formerly Alhó, Hungary)). The reasons behind this were mostly architectural, as the available internal spaces did not, or later only rarely, made it possible for the church to expand upwards freely. This was typically due to financial constraints, and often as a result of regulatory obligations; many churches were constructed with a flat ceiling, sometimes making it difficult to even fit the pulpit altar. In the Hungarian Evangelical-Lutheran churches, organs were usually placed in the gallery above the main entrance (organ loft), opposite the pulpit altar.

The pulpit altars still existing in Hungary can typologically be divided into four larger, and within these, several further smaller groups:

1. Pulpit altars with an accented reredos (retable) behind which the pulpit basket remains hidden; only the pulpit crown or the door leading to the pulpit rise above them. [Figs. 1, 2 and 3]

2. Pulpit altars with an accented reredos and a similarly accented pulpit basket. [Figs. 4, 5 and 6]

3. Pulpit altars built with a pulpit basket composed into the reredos, so that the pulpit has an accented role, constructed within the retable. [Figs. 7 and 8]

4. Pulpit altars that fit into a uniform architectural frame. [Figs. 9 and 10]

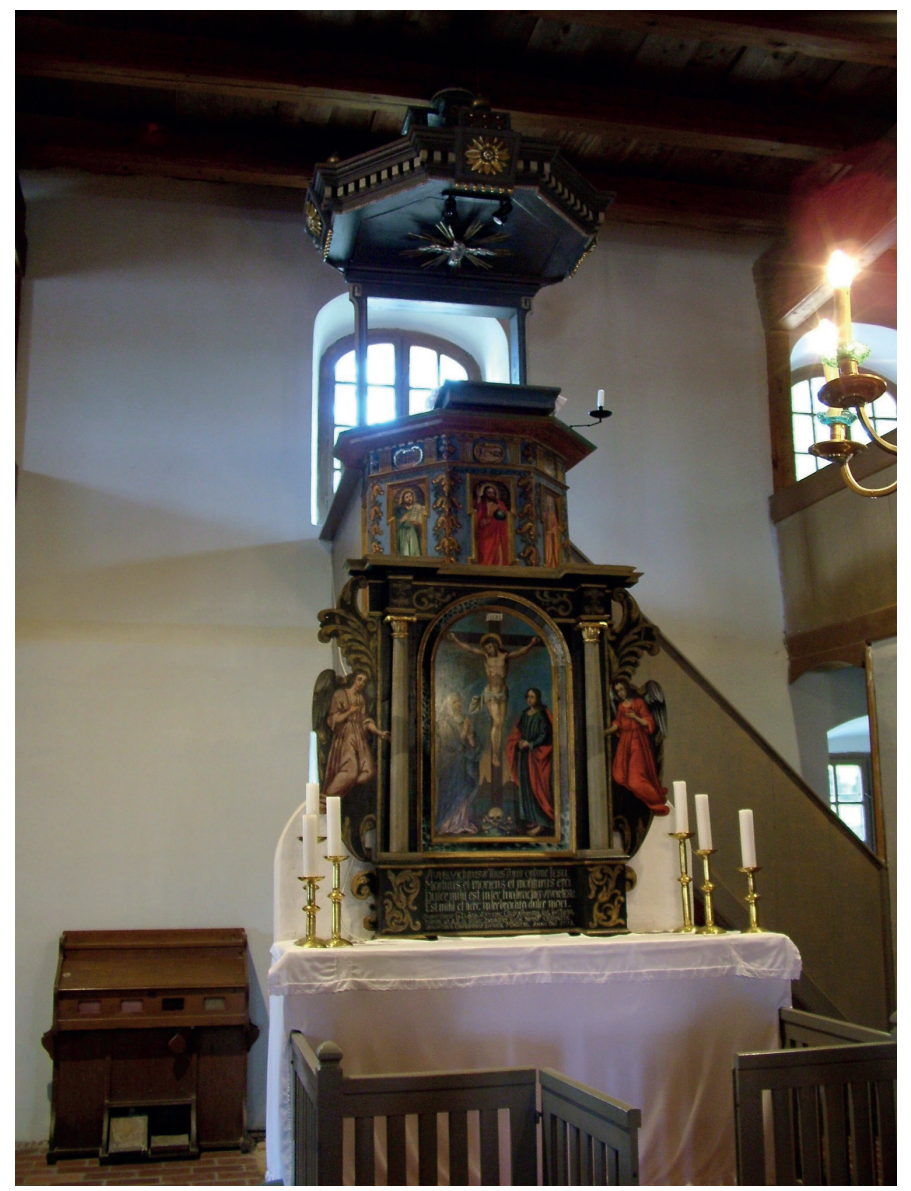

Fig. 1 Nemescsó (Hungary), pulpit altar (Photo by the author) 


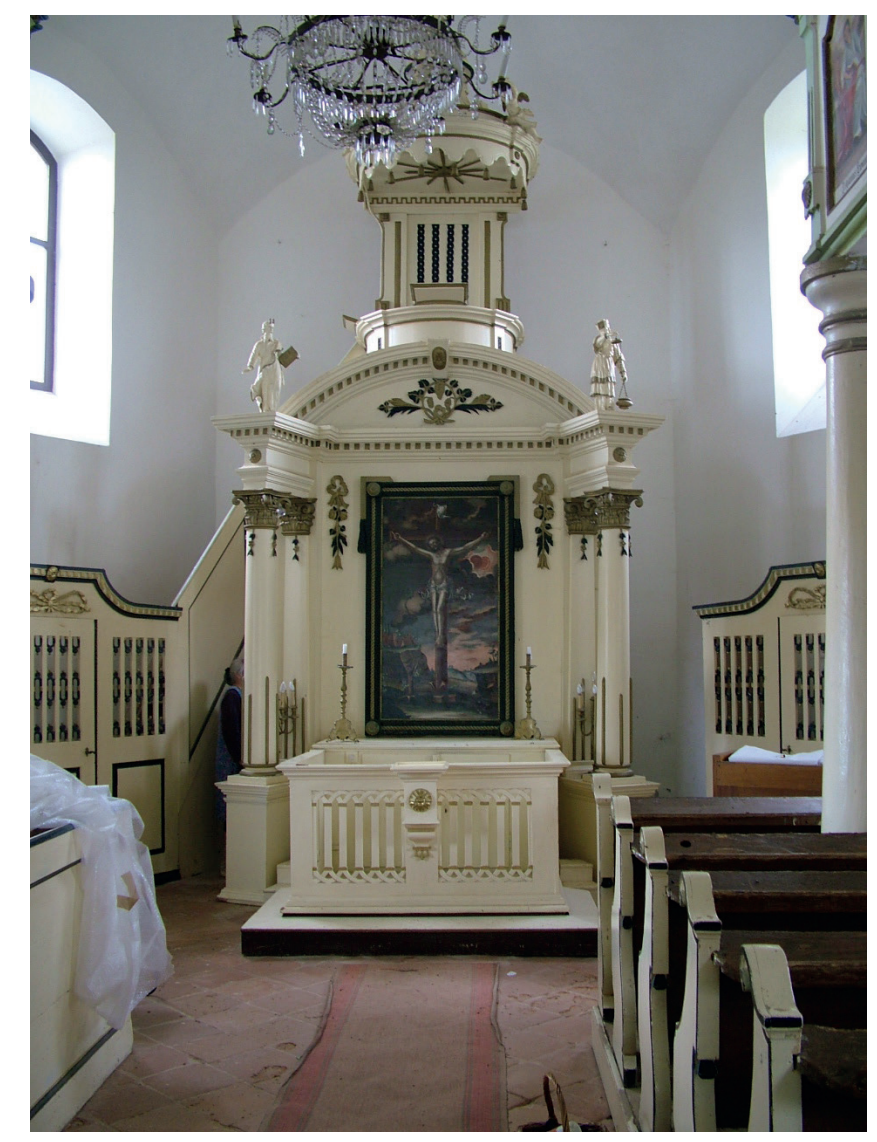

Fig. 2 Keszőhidegkút (Hungary), pulpit altar (Photo by the author)

Pulpit altars as individual constructions usually appear as the focal point of the longitudinal nave, as a perfect closure thereof. It is mostly opposite the main entrance, at the end of the galleries where they markedly embody the liturgical requirements demanded from a cult centre. In the case of the pulpit altars of the first group built with an accented retable, the usually large sized altarpiece was always given a dominant role. The accented main cornice above this was typically ornamented with carved vases or sculptures. In the case of this version, the pulpit basket remained hidden behind the altar wall. In most cases, it was connected to the structure with a frame supplied with a special (whispering) door with an ornamented ridge or simply a wall in a matching style, but its ratio within the pulpit altar never exceeded $33 \%$.

The pulpit basket with its accented appearance above the retable represents the next type of pulpit altar. With these pulpit altars, the pulpit basket gains a significant role by having been placed above the unmodified retable with all its total size and importance. The rich ornamentation suits the altar and highlights the location of the preaching minister. The ratio of the unit composed by the pulpit and the pulpit crown together within the pulpit altar, here, approaches or even reaches the height of the retable, i.e. $50 \%$.

The third type is embodied by pulpits composed into the retable, where, consequently, both the role and the size of the altarpiece is significantly reduced. In these pulpit altars, the

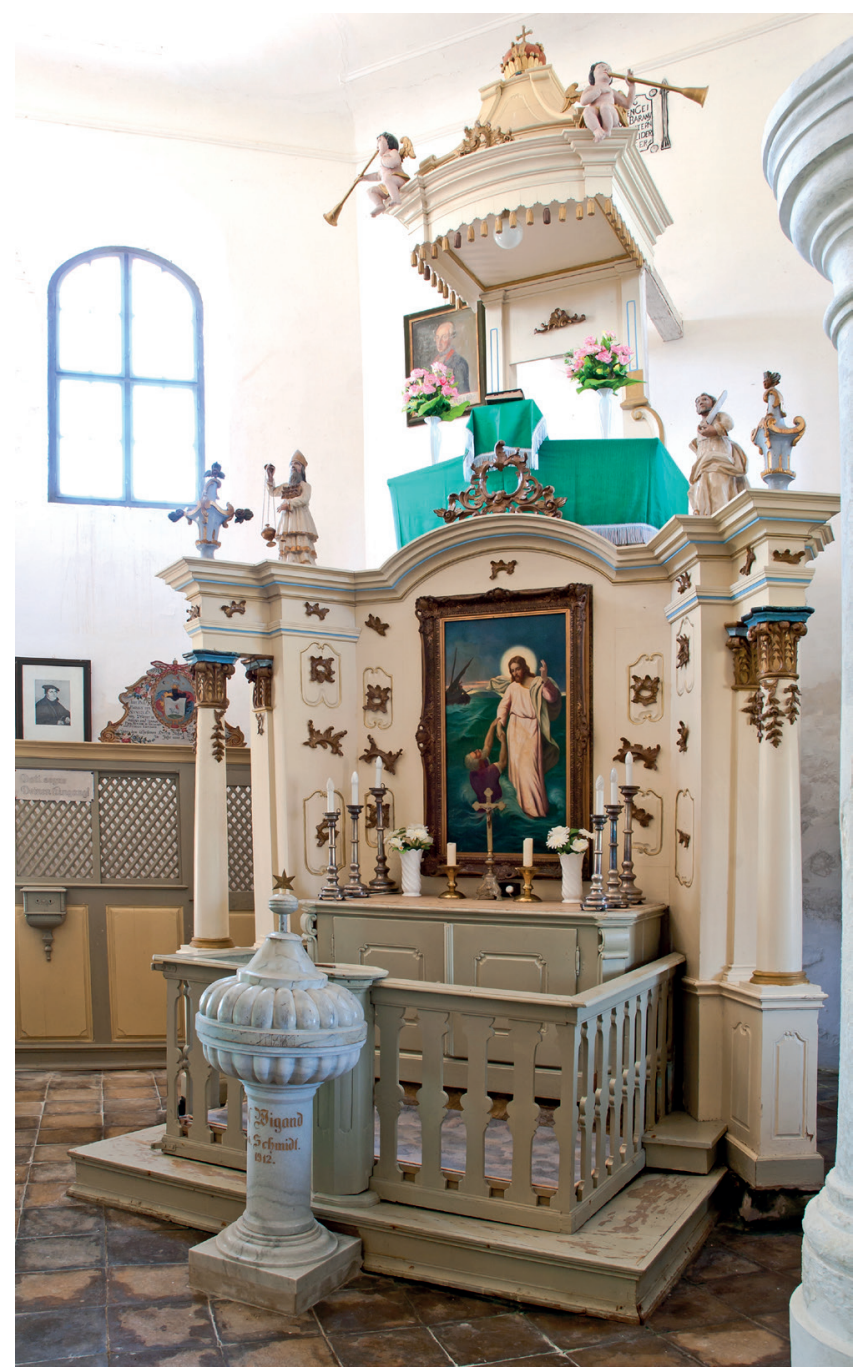

Fig. 3 Varsád (Hungary), pulpit altar (Photo by the author)

altar wall loses its independent and monumental character; it opens up and involves the pulpit basket. There are some pulpit altars of this style existing even now, including those in Bokod, Nagysimonyi, Tés and Tét, among others. The very location of the preacher is somewhat strengthened, both in its appearance and size; the pulpit becomes the most accented element, dominating the original place of the altarpiece, and thus gaining central importance. The altar wall becomes airy, and after having lost its original function (bearing the altarpiece and the pulpit), it only plays an ornamental role. Besides all these (although still being present) the altarpiece appears as a type of predella with its significantly reduced size and proportion compared to the mass of the pulpit.

The fourth type is somewhat exceptional, and it also involves the pulpit altars that, in contrast to those previously, belong to a certain architectural framework. They are embedded into a wooden, brick-walled structure that either close the apse, or, in the absence of this, enclose a curved separated space at the end of an otherwise straight-line closed church. This group consists mostly of pulpit altars organically built into the ornamented wall, containing the stairs to the pulpit and furnished with doors. 


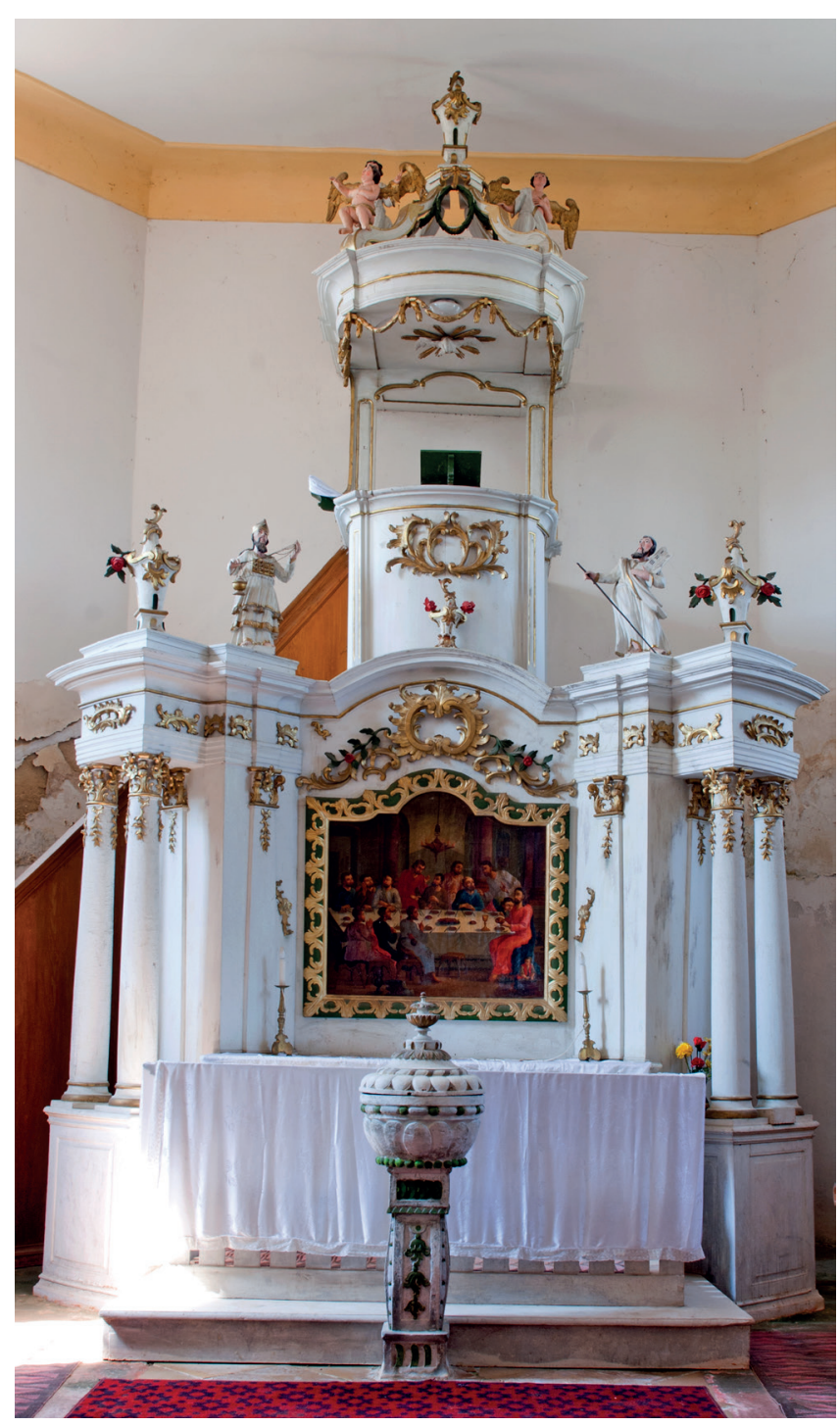

Fig. 4 Felsőnána (Hungary), pulpit altar (Photo by the author)

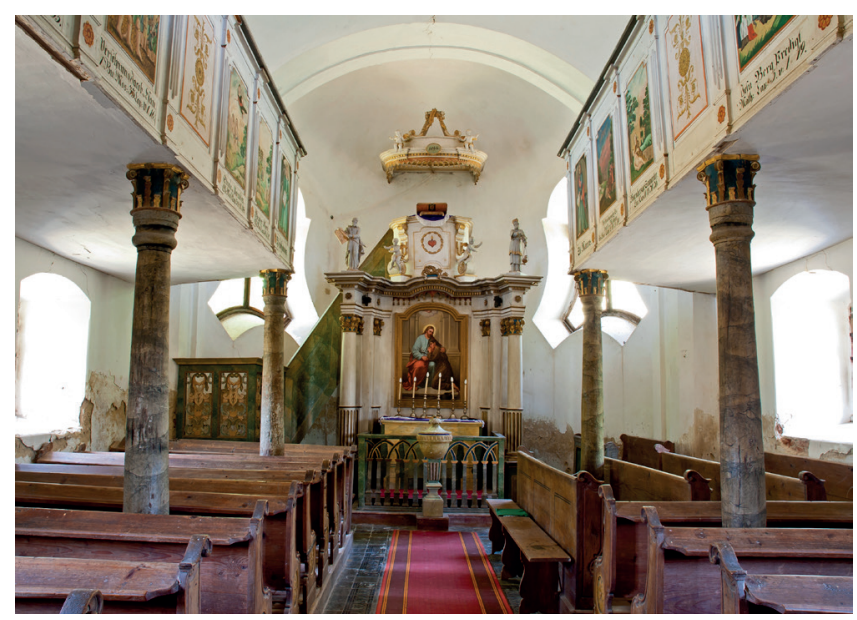

Fig. 5 Murga (Hungary), pulpit altar (Photo by Endre Véssey)

The scene-like walled-off space created like this has nothing to do, either historically or content-wise, with the rood-screens of Catholic churches, as the functions of these two are totally different. The wall separating the space, operating in reality as a sacristy, and a store-room discretely hide the stairs leading

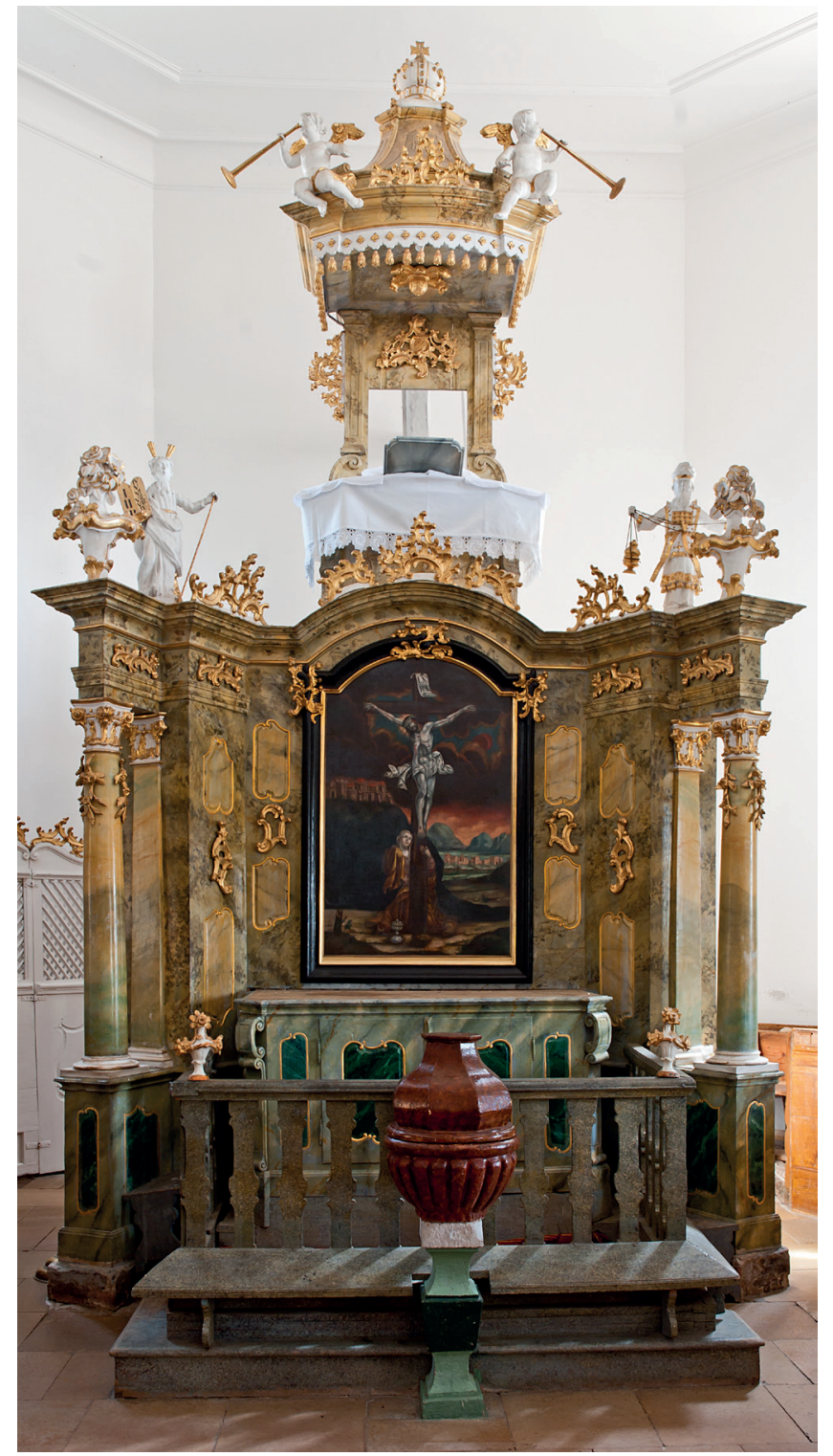

Fig. 6 Sárszentlőrinc (Hungary), pulpit altar (Photo by Endre Véssey)

to the pulpit, and efficiently express the unity of the Word preached and the sacraments with architectural solutions, which thus become physically independent from the very person of the preacher. This method of closing the nave perfectly highlights the cult centre - now also architecturally - and as a result, in the otherwise less decorated space, the effect achieved is as monumental as possible. From the four examples, this is the type which most parallels the German pulpit altars.

From an art historian point of view, what is also interesting about these four categories, is that the structures referred to were not formed one after the other as a result of a lengthy, centuries-long historical, stylistic and liturgical development, but arose almost at the same time, appearing in parallel with each other. This can be seen as explicit proof of the Evangelical-Lutherans arriving from different parts of the world to the Carpathian Basin and those already living there, followed, adopted and applied a diverse range of examples during almost the very same period. (Csepregi, 2009; Granasztóiné Győrffy, 2007). 


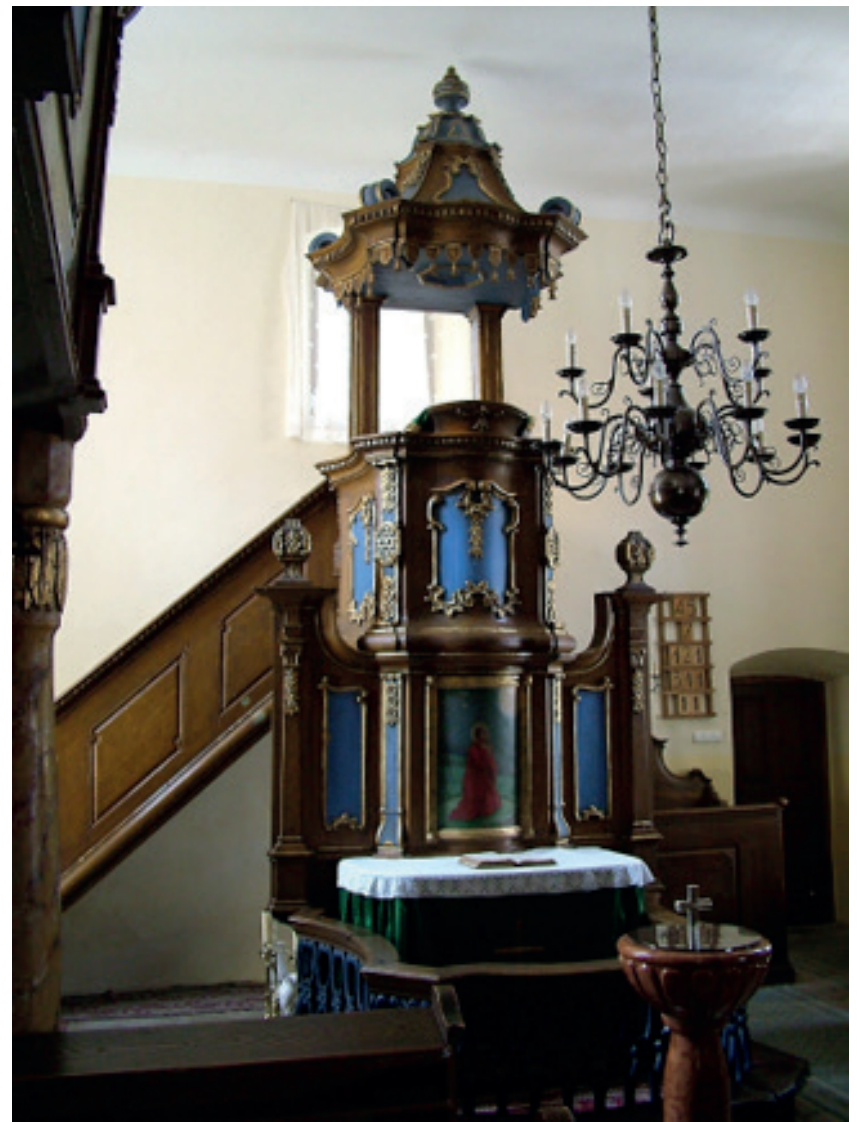

Fig. 7 Bokod (Hungary), pulpit altar (Photo by the author)

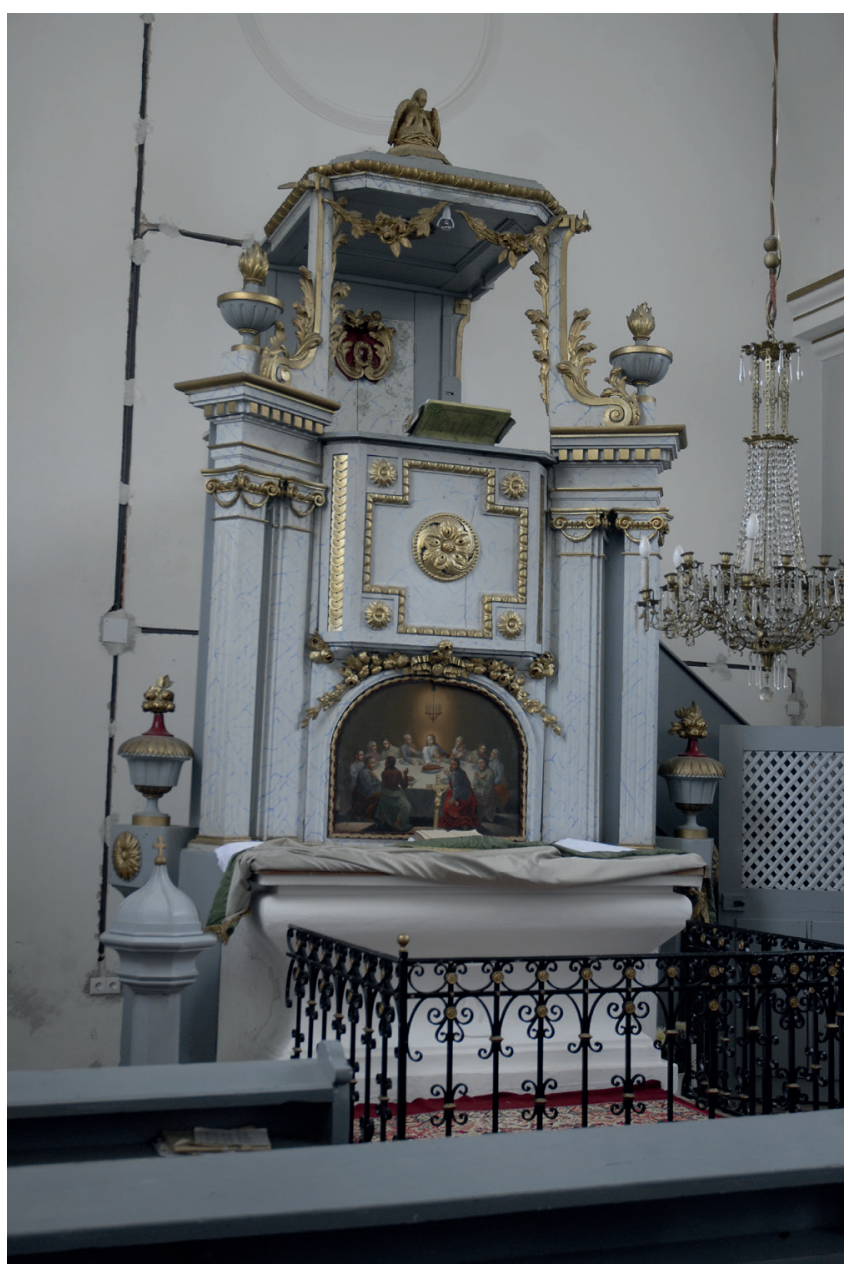

Fig. 8 Tés (Hungary), pulpit altar (Photo by the author)

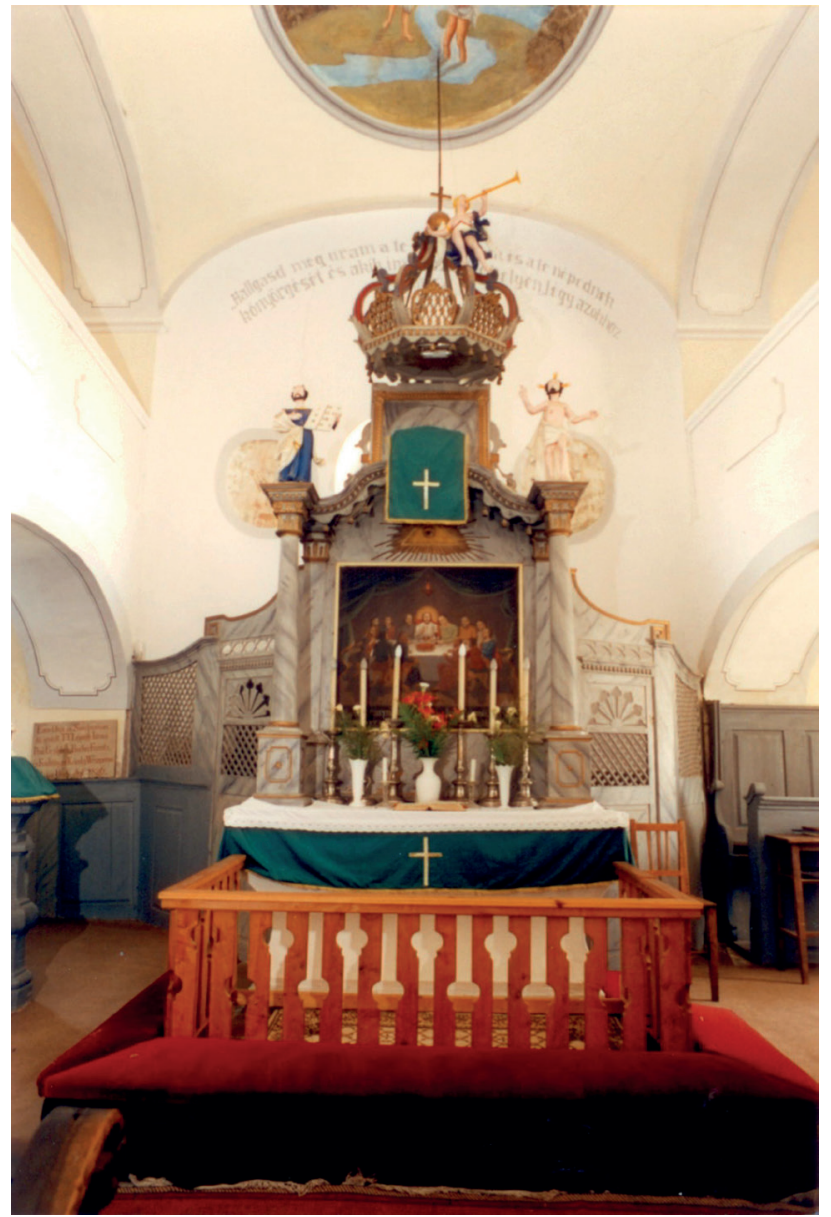

Fig. 9 Kapolcs (Hungary), pulpit altar (Photo by the author)

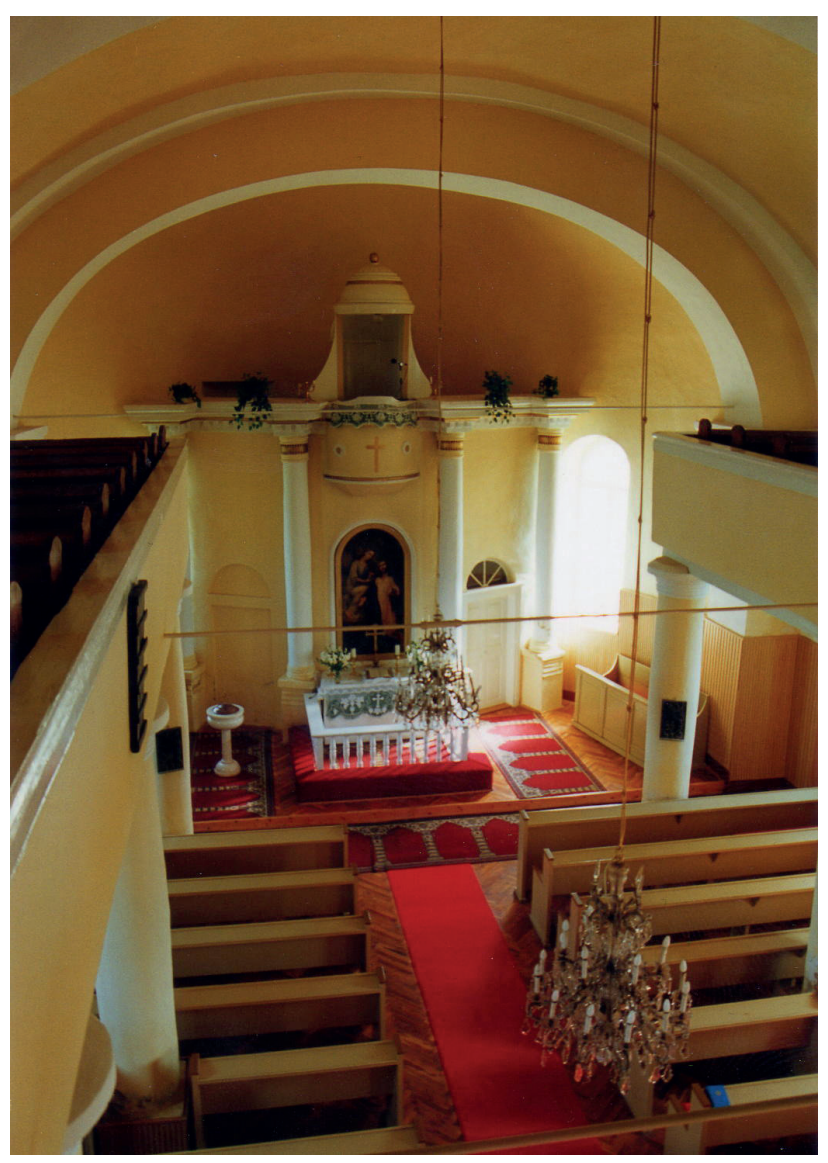

Fig. 10 Porrogszentkirály (Hungary), pulpit altar (Photo by the author) 
Although all four types have their archetypes in German territories, the use of certain types cannot necessarily be linked to any given ethnic group. Moreover, the most frequently used types (i.e. types one and two) have the least connection with the German archetypes. It follows from this that contractors in Hungary applied an alternative design. However, before introducing the author's related theory, another important set of structures also needs to be mentioned.

These are the purchased, amended or assembled pulpit altars that represent a significant and rather exciting group of the structures still in existence. It is possible to confirm the purchases partially from references found in the archives of the congregations and partially, when these are absent, from the styles applied. Furniture such as pulpits, altars and benches originally used by the non-teaching Catholic monastic orders, suppressed by decree, could regularly be cheaply purchased by the evangelicals, well below the normal market price; this was highly beneficial for the financially struggling communities. Based on this paper's current research, the structures purchased and later altered represent $20 \%$ of the now existing materials, which could have significantly influenced the form and development of the locally constructed structures.

Returning to the question of where the most frequent type used in Hungary came from if this type was not widespread among the German Lutheran pulpit altars despite that some elements could be traced to that region? This style comprised a wooden structure framed with two columns or sets of columns coming slightly forward on the two sides of the retable, bearing the main cornice and usually having the altarpiece higher and centrally, where the set of the pulpit crown and the pulpit could be found. In this paper, the hypothesis is that these structures have the most direct relationship with the main and side altars of some Hungarian Catholic churches.

The compositions framed by the accented columns and the strong cornice moulding usually filled the entire apse of Catholic churches. It may be that the altars of smaller rural parish churches, dating back to the $18^{\text {th }}$ century, were the direct predecessors of the Lutheran pulpit altars, which, partially as a result of the location of the pulpit, were implemented with a reduced size, a simplified external form and amended crests. Of course, there were several types and forms of the Catholic main and side altars built at the end of the $17^{\text {th }}$ and the beginning of the $18^{\text {th }}$ century, not only the retable altar framed by columns. However, this is the structure that, for several reasons, best suits the concept of the Lutheran pulpit altar. It is the only structure among Catholic altars suitable for bearing the load of the pulpit and the minister (with the necessary reinforcement at the back); also, this solution was relatively easy to aesthetically harmonise with the mass of the pulpit-pulpit crown.
The majority of carpenters and other artisans working on the wooden pulpit altars in Hungary might have been local or recently settled people, who until the Hungarian Edict of Tolerance could only receive church assignments for the furnishing of Catholic churches under reconstruction in the territories liberated from the Ottoman oppression (and elsewhere). Almost 50 years following the first settlements, after 1781, at the time when there appeared an increasing demand for the new altar form, these craftsmen found it natural to apply the already known and most suitable forms, amending them in accordance with the customers' demands. This continuous improvement might have been the reason why, in the beginning, in the case of the pulpit altar, the pulpit basket remained hidden behind the retable, and it was only the pulpit crown that was elevated above the structure. Assembling the various parts did not always result in a perfect structure, and the traces of this can be recognised in various instances. It can be seen how the builders were striving with the implementation of this new task.

For the author, the evolution of the Hungarian typology of pulpit altars is undoubtedly about the local interrelations alongside the indisputable European effects. It is about how the residents of a given settlement tried to apply that which they experienced abroad in their own environments, reacting also to the local circumstances. Finally, quoting from Lajos Fülep again, in his previously mentioned paper, written in 1951:

"...let us learn that in great artistic eras, the general character of style is of a great artistic value in itself, and our less polished, maybe rougher folkish products are not only the archaeological additives of scientific research but just as alive as the greatest ones, giving the same pure, undisturbed joy. It is not too difficult to show the magnificence of the great - let us see the magnificence of the small, because it is definitely there."

\section{References}

Csepregi, Z. (2009). Das königliche Ungarn im Jahrhundert vor der Toleranz (1681-1781). (The Kingdom of Hungary in the century of the Edict of Tolerance.) In: Leeb, R., Scheutz, M., Weikl, D. (ed.) Geheimprotestantismus und evangelische Kirchen in der Habsburgermonarchie und im Erzstift Salzburg (17./18. Jahrhundert). Wien-München, pp. 299-330. (in German)

Fülep, L. (1951). A magyar művészettörténelem föladata. (The task of Hungarian art history.) Az MTA Társadalmi-Történeti Tudományok Osztályának Közleményei 3. Muzeológiai Sorozat: Régészet, Néprajz, Müvészettörténet. 2(1), pp. 3-24. (in Hungarian)

Granasztóiné Győrffy, K. (2007). A nemescsói evangélikus templom szószékoltára. (The pulpit-altar of Nemescsó.) In: Magyar Műemlékvédelem - Az Országos Műemléki Felügyelőség Kiadványai, Budapest, pp. 87-98. (in Hungarian)

Kósa, L. (1993). Egyház, társadalom, hagyomány. (Church, Society, Tradition.) Debrecen. (in Hungarian) 